\title{
URGENSI PENUMBUHKEMBANGAN NASIONALISME DI TAPAL BATAS DESA AJI KUNING SEBATIK KALIMANTAN UTARA
}

Urgency to Growth Nationalism in Border Area in Aji Kuning Village Sebatik North Kalimantan

\author{
Roby Zulkarnain Noer ${ }^{*}$ \\ ${ }^{1}$ Jurusan PGSD, Fakultas Keguruan dan Ilmu Penddidikan, Universitas Borneo Tarakan, \\ Jl. Amal Lama Nomor 1 Tarakan \\ * Penulis Korespodensi : robyznoer@gmail.com
}

\begin{abstract}
ABSTRAK
Rasa nasionalisme dalam kehidupan berbangsa perlu digalakkan sebagai upaya memberikan kesadaran pada masyarakat. Permasalahan utama pendidikan terutama pada karakter rasa nasionalisme banyak terjadi di daerah $3 T$ (Terdepan, Terluar dan Tertinggal). Mengatasi permasalahan tersebut perlu dilakukan sosialisasi. Sosialisasi ini diharapkan memberikan kontribusi pada masyarakat di daerah perbatasan termotivasi untuk lebih memiliki semangat nasionalisme, sehingga memiliki kebanggaan sebagai bangsa Indonesia dan memiliki nilai karakter dan berjiwa Pancasila. Metode pelaksanaan dilakukan dengan melakukan strategi pelaksanaan kegiatan yang dilakukan meliputi sosialisasi, seminar nasionalisme dan evaluasi. Hasil seminar ini didapatkan hasil sebelum dan setelah seminar, yaitu: pada aspek budaya Indonesia terjadi peningkatan dari $20.4 \%$ menjadi $88 \%$, pada aspek budaya lokal dari $56 \%$ menjadi $85 \%$, aspek kewarganegaaran $27.4 \%$ menjadi $83 \%$ dan aspek pancasila $20.4 \%$ menjadi $78 \%$.
\end{abstract}

Kata Kunci: Nasionalisme, Daerah $3 T$

\begin{abstract}
The sense of nationalism in the life of the nation needs to be encouraged as an effort to provide awareness to the community. The main problem of education on the character of nationalism much happen in the area of $3 T$ region ( Terdepan (Front region), Terluar (Outermost) and Tertinggal (Disadvantaged)). To Solve the problem needs to be socialized. This socialization is expected to contribute to the community in the areas that are motivated to have more spirit of nationalism, so have pride as the nation of Indonesia and have the character and spirit of Pancasila. The implementation method is carried out by implementing the strategy of the implementation of the activities carried out by the socialization, the seminar of nationalism and evaluation. The results of this seminar are obtained before and after the seminar, which is: on the cultural aspect of Indonesia Increased from $20.4 \%$ to $88 \%$, on the local cultural aspects from $56 \%$ to $85 \%$, the aspect of citizenship $27.4 \%$ to $83 \%$ and aspects of Pancasila $20,4 \%$ to $78 \%$.
\end{abstract}

Keywords: Nasionalisme, $3 T$ Region

Bangsa Indonesia adalah banyak yang besar, bangsa yang lahir dari beragam kebudayaan yang berbeda, bangsa yang mempunyai banyak pulau dan potensi sumber daya alam yang melimpah serta dikenal dengan negara maritim, untuk mempersatukan keberagaman itu maka perlu adanya jiwa kesatuan dan persatuan serta jiwa-jiwa yang memiliki rasa nasionalisme yang tinggi. Rasa nasionalisme dalam pendidikan dipertegas pada UU Nomor 20 Tahun 2003 yang menyatakan bahwa pendidikan adalah usaha sadar dan terencana untuk mewujudkan suasana belajar dan proses pembelajaran agar siswa secara aktif mengembangkan potensi dirinya untuk memiliki kekuatan spiritual keagamaan, pengendalian diri, kepribadian, kecerdasan, akhlak mulia, serta keterampilan yang diperlukan dirinya, masyarakat, bangsa dan negara. Upaya pemerintah dalam 
pengimplementasian nasionalisme tergambar dalam pendidikan karakter di lembaga pendidikan, salah satu karakter yang muncul dalam pendidikan karakter adalah semangat kebangsaan yaitu rasa nasionalisme. Nasionalisme dalam pendidikan karakter merupakan harapan pemerintah kepada generasi bangsa, sehingga muncul generasi dengan ketinggian budi pekerti atau karakter serta memiliki rasa nasionalisme yang tinggi (Wibowo: 2013).

Rasa nasionalisme dalam kehidupan berbangsa perlu digalakkan sebagai upaya memberikan kesadaran pada masyarakat. Peningkatan kesadaran masyarakat akan nilai-nilai luhur budaya bangsa adalah sarana untuk membangkitkan semangat nasionalisme, dengan senantiasa memupuk rasa persatuan dan kesatuan bangsa dan bernegara dalam kehidupan bermasyarakat. Hal tersebut harus direalisasikan secara cepat dan tepat karena mengingat permasalahan pendidikan yang terjadi di Indonesia terutama daerah yang berbatasan langsung dengan negara lain dengan menanamkan 18 nilai karakter tersebut: Religius, Jujur, Toleransi, Disiplin, Kerja keras, Kreatif, Mandiri, Demokratis, Rasa ingin tahu, Semangat kebangsaan atau Nasionalisme, Cinta tanah air, Menghargai Prestasi, Komunikatif, Cinta damai, Gemar membaca, Peduli lingkungan, Peduli sosial, Tanggung jawab.

Permasalahan utama pendidikan terutama pada karakter rasa nasionalisme banyak terjadi di daerah 3T (Terdepan, Terluar dan Tertinggal). Menurut LPDP (Lembaga Pengelola Dana Pendidikan) Daerah 3T yang terletak di Provinsi Kalimantan Utara adalah Kabupaten Nunukan Kecamatan Sebatik Desa Aji Kuning. Permasalahan utama terkait rasa nasionalisme yang biasa terjadi di daerah
Sebatik yaitu melakukan transaksi menggunakan dua mata uang yaitu Rupiah dan Ringgit dan juga tidak konsistennya penggunaan bahasa Indonesia sebagai bahasa nasional, penggunaan bahasa cenderung mengikuti negara tetangga (bahasa Melayu atau Malaysia). Tidak konsistennya penggunaan bahasa Indonesia disebabkan kurangnya guru yang profesional pada pendidikan dasar. Permasalahan keprofesionalan guru mempengaruhi proses pembelajaran yang jarang menggunakan bahasa Indonesia yang baik dan benar. Data Dinas Pendidikan Kabupaten Nunukan menunjukkan bahwa Pemerintah Kabupaten Nunukan masih kekurangan guru untuk berbagai jenjang dirincikan sebagai berikut jenjang SD sebanyak 350 orang, SMP sekitar 500 orang dan SMA sebanyak 700 orang, SMA 100 orang. Serta kualifikasi pendidikan guru yang belum sesuai. Data dari Dinas Pendidikan Kabupaten Nunukan (2016) juga menunjukkan jenjang pendidikan terakhir guru di Nunukan untuk tenaga pendidik 2.545 orang dimana 50 persen dari itu merupakan tenaga honorer dengan latar belakang pendidikan hanya ijazah SMA. Hal tersebut berpengaruh terhadap perilaku siswa terutama rasa nasionalisme.

Pengenalan rasa nasionalisme kepada siswa SD dapat dilakukan dengan banyak cara, salah satunya adalah dengan penerapan kebiasaan seperti konsistensi dalam penggunaan bahasa Indonesia yang baik dan benar, mengaplikasikan teori dalam pelajaran PKn, seperti bercerita kisah para pahlawan, menonton film perjuangan seperti ditayangkan film dokumenter. media pembelajaran yang disisipi hal-hal terkait aspek nasionalisme. Selain itu upaya lain yang dilakukan untuk menumbuhkembangkan nasionalisme masyarakat di perbatasan yaitu dengan 
program sosialisasi yang berhubungan dengan nasioanalisme menyajikan bagaimana upaya pendidikan karakter dan dapat memberikan informasi penumbuhkembangan rasa nasionalisme dibalut dengan sajian informasi masyarakat pada daerah terluar di Daerah 3T, terutama di Desa Aji Kuning, Kecamatan Sebatik Tengah Kabupaten Nunukan Provinsi Kalimantan Utara. Dengan adanya kegiatan ini diharapkan memberikan kontribusi pada masyarakat di daerah perbatasan termotivasi untuk lebih memiliki semangat nasionalisme, sehingga memiliki kebanggaan sebagai bangsa Indonesia dan memiliki nilai karakter dan berjiwa Pancasila.

\section{METODE}

Metode pelaksanaan dilakukan dengan melakukan strategi pelaksanaan kegiatan yang dilakukan meliputi sosialisasi, seminar nasionalisme dan evaluasi. Rencana kegiatan tersebut dimulai dari tahap pengumpulan data sekunder, sosialisasi dan melakukan seminar bertemakan nasionalisme di daerah perbatasan. Dengan program sosialisasi dan seminar nasionalisme ini diharapkan mampu menumbuhkembangkan rasa nasionalisme sehingga masyarakat di daerah perbatasan bangga menjadi bangsa Indonesia. Strategi pelaksanaan yang akan digunakan untuk mencapai tujuan yang diharapkan melalui sebagai berikut:

1. Melaksanakan metode sosialisasi yang tepat dan menarik sehingga masyarakat lebih termotivasi dan memupuk rasa nasionalisme.

2. Mengadakan Seminar nasionalisme yang mengundang beberapa elemen masyarakat.

3. Evaluasi disetiap kegiatan yang telah dilaksanakan.
Implementasi program dilaksanakan sesuai dengan rencana program yang telah dirancang sebelumnya. Tahapan-tahapan pelaksanaan program adalah sebagai berikut:

1. Sosialisasi dan pengenalan nasionalisme dengan presentasi, pemutaran video atau film pendek mengenai nasionalisme.

2. Seminar nasionalisme menyampaikan semua yang berkaitan dengan nasionalisme, sehingga masyarakat di daerah perbatasan memiliki kesadaran yang tinggi akan nasionalisme.

3. Evaluasi secara umum untuk mengetahui progres perubahan masyarakat daerah sebatik yang berada di perbatasan apakah ada peningkatan rasa nasionalisme setelah dilakukan sosialisasi dan seminar nasionalisme.

\section{HASIL DAN PEMBAHASAN}

Negara Indonesia adalah yang beberapa wilayahnya berbatasan langsung dengan negara tetangga. Seperti halnya di Provinsi Kalimantan Utara terdapat salah satu pulau yang berbatasan darat dengan Malaysia yaitu di Pulau Sebatik. Pulau Sebatik terbagi menjadi dua bagian wilayah utara pulau itu seluas $187,23 \mathrm{~km}^{2}$, menjadi milik Malaysia, sedang wilayah bagian selatan seluas $246.61 \mathrm{~km}^{2}$ adalah milik Indonesia di Desa Aji Kuning. Konflik perbatasan bukan konflik yang kecil, namun menjadi konflik yang harus secara sigap dan cepat ditangani oleh pemerintah, jika tidak maka akan berkepanjangan ataupun berkesinambungan dan menyangkut berbagai aspek sosial dan ekonomi, budaya dan aspek lainnya. Konflik ini nantinya akan berpengaruh pada nasionalisme masyarakat yang berdomisi di daerah perbatasan. Berdasarkan hasil observasi permasalahan terkait nasionalisme di Desa Aji Kuning Sebatik yaitu masyarakat umumnya lebih memilih transaksi menggunakan uang Ringgit dibanding mata uang Rupiah dengan dalil transaksi menggunakan uang Ringgit lebih 
mudah dan nilainya lebih murah dibandingkan Rupiah.

Observasi pada aspek pendidikan didapatkan siswa lebih banyak menggunakan bahasa Melayu Malaysia karena di lingkungan tempatnya orangtua dan masyarakat lebih dominan dan fasis menggunakan bahasa Melayu Malaysia. Hal ini merupakan beberapa fakta yang terjadi di Desa Aji Kuning Sebatik. Permasalahan nasionalisme ini akan mendarah daging di masyarakat perbatasan jika masih ketergantungan masyarakat yang besar kepada negara tetangga, mulai dari sembako dan produk-produk lain untuk mencukupi kebutuhan setiap hari. Sehingga di kalangan masyarakat Sebatik tidak asing lagi terdengar semboyan "Garuda di dada ku Malaysia di Perut ku", itu semua terjadi karena jurang kemakmuran amat lebar jika dibandingkan tingkat kesejahteaan masyarakat di negara tetangga. Pesona dan daya tarik kemakmuran di seberang perbatasan membuat WNI di kawasan perbatasan tersebut harus menyeberang untuk mengadu nasib.

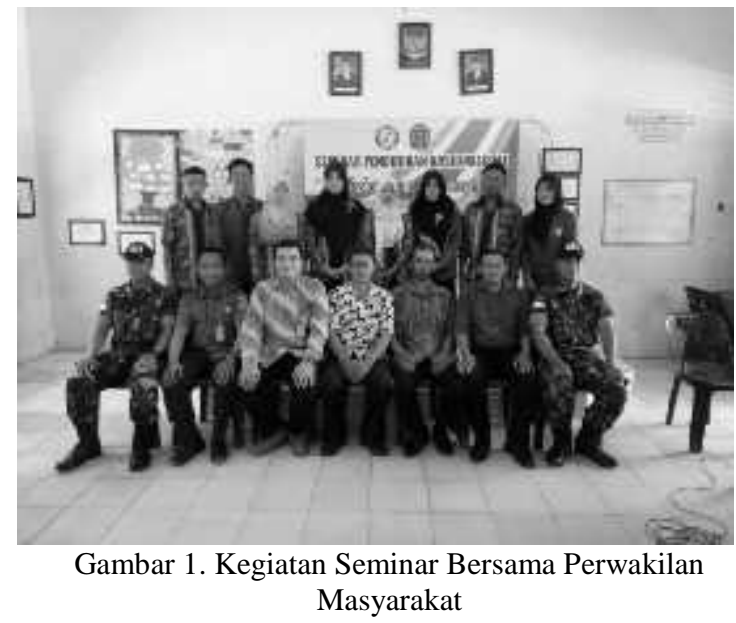

Pada saat seminar dilakukan beberapa pemaparan terkait urgensi peningkatan nasionalisme, terutama di Sebatik. Pemerintahan Presiden Jokowi yang berupaya membangun Indonesia dari daerah pinggiran atau perbatasan, patut untuk didukung. Sebatik merupakan beranda depan negara Indonesia sehingga selain upaya yang dilakukan pemerintah masyarakat juga perlu diberikan pemahaman dan kesadaran nasionalisme sebagai upaya meningkatkan nasionalisme di daerah perbatasan. Perbaikan yang tidak kalah penting yaitu di sektor pendidikan mulai dari pendidikan dasar siswa harus ditanamkan rasa nasionalisme dan cinta tanah air sehingga terbentuknya jiwa patriotisme pada diri siswa serta rasa bangga menjadi warga Indonesia. Pendidikan karakter dengan 18 nilai karakter juga wajib untuk selalu diajarkan tidak sebatas teori tapi diimplemtasikan sehingga pemahaman anak terkait nasionalisme tidak abstrak. Peran guru di daerah perbatasan sangat berat karena guru harus benar-benar mendidik siswa tidak hanya pandai di bidang akademik tetapi bagaimana menjadikan siswa mulai sejak dini mencintai tanah airnya numbuhkan rasa nasionalismenya.

Evaluasi yang dilakukan meliputi pemahaman masyarakat terkait nasionalisme, yang terdiri dari pengetahuan tentang pancasila, kewarganegaraan, budaya lokal dan Indonesia. Pengukuran menggunakan angket dan wawancara yang berisi beberapa poin pertanyaan. Evaluasi dilakukan sebelum dan setelah melakukan seminar Berdasarkan hasil evaluasi didapatkan hasil sebagai berikut

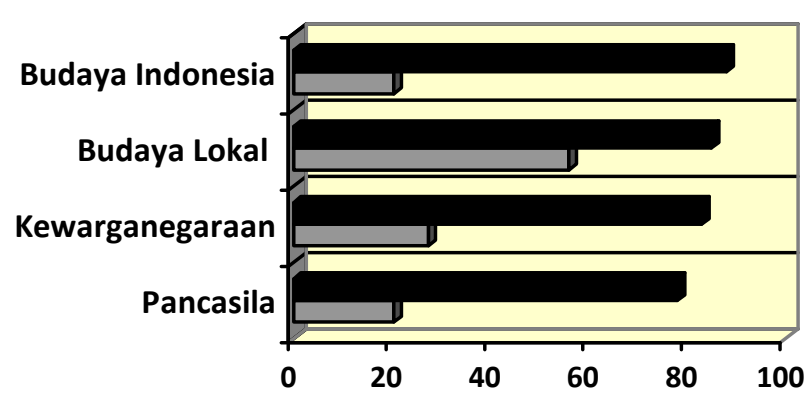

Gambar 2. Persentase Pengetahuan Masyarakat Sebelum dan Setelah Seminar

Berdasarkan hasil tersebut didapatkan hasil bahwa pengetahuan masyarakat banyak mengalami peningkatan antara sebelum dan setelah dilakukan seminar. Pada aspek budaya Indonesia terjadi peningkatan dari $20.4 \%$ menjadi $88 \%$. Pada aspek budaya 
lokal dari $56 \%$ menjadi $85 \%$. Aspek kewarganegaaran $27.4 \%$ menjadi $83 \%$. Aspek pancasila $20.4 \%$ menjadi $78 \%$. Peningkatan nilai terjadi karena beberapa aspek penting terkait hal nasionalisme banyak didiskusikan selama proses seminar berlangsung, sebagai contoh pengenalan budaya lokal dan budaya Indonesia, materi kewarganegaraan dan lain-lain.

\section{PENUTUP}

Hasil dari kegiatan ini adalah:

1. Sosialisasi dilakukan dengan melakukan seminar meliputi beberapa aspek pengenalan nasionalisme yaitu terkait pancasila, kewarganegaraan, budaya lokal dan budaya Indonesia.

2. Berdasarkan hasil evaluasi didapatkan hasil sebelum dan sesudah seminar. Pada aspek budaya Indonesia terjadi peningkatan dari $20.4 \%$ menjadi $88 \%$. Pada aspek budaya lokal dari 56\% menjadi $85 \%$. Aspek kewarganegaaran $27.4 \%$ menjadi $83 \%$. Aspek pancasila $20.4 \%$ menjadi $78 \%$.

Saran setelah dilakukan seminar ini adalah perlu adanya upaya yang berkesinambungan oleh pemerintah dalam pengenalan dan penguatan nasionalisme di daerah perbatasan untuk lebih memperkuat jiwa nasionalisme masyarakat perbatasan.

\section{DAFTAR RUJUKAN}

Dino. (2013). Nasionalisme Masyarakat Perbatasan di Desa Siding, Kecamatan Siding, Kabupaten Bengkayang. Pontianak: Universitas Tanjungpura Pontianak.

Kohn, H. (1965). Nasionalisme dan arti sejarahnya. Jakarta: Erlangga.

Nilasari , F. D. 2014. Representasi Nasionalisme Warga Perbatasan Kalimantan Barat Dalam Film. Semarang: Universitas Diponegoro.

Smith, D. A. (2003). Nasionalisme Teori, Ideologi, Sejarah. Jakarta: Erlangga. 